\title{
RENEGOTIATION-THE MYTH OF REPRICING
}

\author{
EDWARD B. BURIING*
}

$\mathrm{R}^{\mathrm{n}}$

ENEGOTIATION" has an appealing sound. Any program to take the profit out of war is fine. Do we want to stop warprofiteering? Do we want to reduce extortionate prices for war materials? We do. It seems easy to declare that every contract for the purchase by the Government of war materials shall be re-negotiated; if the price is too high, it shall be reduced; if the price has already been paid, the excessive portion shall be refunded to the Government.

The original thought was that the procurement agencies should be given power to correct extortionate prices in the contracts made by them. Prime Government contractors were the ones concerned. The long controversy with the Bethlehem Shipbuilding Company over the profits of that company in the first World War led to an agitation for the control of such profits in the present war. ${ }^{x}$

But then came up the question of sub-contractors. A shipbuilder who had made a contract with the Navy to build two warships might have sublet a contract for one. It would not do to permit the sub-contracting shipyard to keep excessive profits if the profits of the main contracting shipyard were to be trimmed. Therefore the original act of April 2I, I942, provided for the renegotiation of "contracts and subcontracts." There was no definition in the original act of the term "subcontract." According to all the dictionaries the term "subcontract" was limited to persons who undertook to perform a part of a prime contract.

After the enactment of the original act, during the summer of r942, the various procurement agencies set out to apply the statute. Then the usual thing happened. As is the case with most administrators, they wanted to enlarge their powers. They were not content with the power to renegotiate prime contracts and true subcontracts. They attempted to include persons not covered by the customary definition' of "subcontractor." They wished to extend their powers to cover persons furnishing

* Of the Washington, D.C., Bar.

I See United States Bethlehem Steel Corp., 3I5 U.S. 289 (I942).

$=$ The original act is Section 403, Title IV, of the Sixth Supplemental National Defense Appropriation Act of 1942, approved April 28, 1942. It covers three pages. The amended act is Title VIII of the Revenue Act of I942, approved October 2I, 1942. It covers five pages. The last amendment is Title VII of the Revenue Act of 1943, passed over a veto February 25, I944. It covers sixteen pages. The subject is a growing one. 
raw materials and standard articles to be incorporated into a prime article. ${ }^{3}$

Accordingly representatives of the War and Navy Departments and the Maritime Commission appeared in September, 1942 , before a subcommittee of the Senate Finance Committee. They presented an elaborate draft of an amendment, which included suppliers of raw materials and standard fabricated articles but excluded "articles for the general operation or maintenance of the contractor's plant." 4 This draft, however, was discarded and a definition of subcontract adopted which covered in general terms the furnishing of "articles required for the performance of a contract or subcontract." 5

The contractor's price for the prime article is affected by a myriad of subordinate prices. Our shipbuilder buys engines from $X$, who buys steel from $Y$, who buys coal from $Z$. Not only that, but $X, Y$, and $Z$ buy a multitude of other items: soap, stepladders, pins, needles, thermometers, nuts, bolts, screws, tools, eggs, coal, bananas, Coca Cola, vitamins, etc., etc. The vendors of all these articles may be making large profits. The prices they exact from their vendees may be claimed to affect the price of the warship. But the contracts made by these suppliers for the sale of these articles are remote from the contract for the ship. They may be very far removed. Are these then contracts with the Government which the Government can re-negotiate? How can the Government re-negotiate a contract that it did not negotiate in the first place-that was negotiated by $\mathrm{X}$ with $\mathrm{Y}$ ?

The Colgate Company may sell soap to a jobber, who sells it to a druggist, who sells it for the washroom of a company making a spare part for the Chrysler Company, which is building a truck to be used in the shipyard. Colgate does not know the ultimate destination of the soap. However, the thousand and one supply contracts made by Colgate, and

\footnotetext{
${ }^{3}$ In August, 1942, the Board of Tax Appeals, in a case under the Vinson-Trammel Act (Aluminum Company of America v. Commissioner, 47 B.T.A. 543) had held that the term "sub-contractor" as used in that act did not include materialmen or suppliers of raw materials or standard commercial articles.

4 Anyone interested should read the legislative history which led to the amendment of October 21, 1942. The draft of amendment submitted specifically excluded articles intended for the general operation and maintenance of the contractor's plant. And in response to inquiries from Senators the representatives stated unequivocally that the draft submitted did not give them power over articles not intended to be incorporated into a prime article. They clearly drew the line between general factory supplies-coal, tools, pins, needles, soap, paper, etc.-and materials intended to be incorporated into a prime article-the subject of a war contract.
}

$s$ The Revenue Act of 1943 , passed over the veto February 25, 1944, repeats the definition found in the 1942 Revenue Act. 
other manufacturers all the way down the line, may affect the price of the ship. If you are going to do a thorough job, you must renegotiate the hundreds of supply contracts made by hundreds of manufacturers with thousands of distributors.

In theory the price adjustment boards claim that authority under the October, I942, amendment. In theory they assert the authority to reach not only contractors and true subcontractors but also all persons who supply articles used not only in the factory of a contractor, but used in the factory of other suppliers of any tier, down to the $n$th degree. The basis of this claim is that all these supplies are "required" in some degree for the performance of the prime contract.

This broad power is claimed whether employed or not. Practically, of course, they cannot employ a fraction of the theoretical power. They claim absolute power with the discretion when to exercise it and over whom. The act is administered on that basis. It is avowedly a selective process. It is defended on that ground.

At this point one begins to re-examine the whole process. What was originally a simple repricing of war materials bought by the Government seems to have developed into something different. When we apply the term "subcontractor" to everybody who in any way may affect the ultimate price, we are going beyond our original purpose. It is one thing for the Government to correct the price it pays for a ship. A different set of questions arises when it attempts to deal with suppliers (who have not contracted with the Government) of general commodities, such as coal, soap, brooms, tools, etc., which are sold to a jobber and then distributed to countless purchasers, one of whom may be a company which supplies something to our hypothetical shipyard.

It is difficult any longer to describe the process as "repricing." You can perhaps defend the re-negotiation of contracts with the Government as a "repricing" process. Especially if the contract has not been completed, it may be all right to authorize the War Department to correct the price. Even if the contract has been completed and the price paid, it may still (by stretching the term) be called "repricing" to authorize the War Department to correct the price by demanding a refund of the excess.

But you get into different waters when you attempt to deal with sales to jobbers by manufacturers of general factory supplies. They had no negotiations with the War Department. There is no contract to be renegotiated. Colgate did not know that the soap which it sold to its jobber was destined ultimately to affect a war contract. If the jobber chose to sell the soap for civilian purposes, no one could touch the price that Col- 
gate received. If, however, the jobber, over whom Colgate had no control, happened to sell it to someone who was in the chain of a war contract, then the War Department attempts to do something about it.

The Government has a dual capacity. On the one hand it is a buyer of commodities-in wartime an enormous buyer. In that aspect it is just like any big corporation-for example, the United States Steel Corporation. It also is a lawmaking body. As a buyer, it directs a repricing of goods that it buys. As one party to a purchase contract, it directs its agent-the Secretary of War - to pay the seller a lower price. But how can it correct the price paid by the distributor who buys from Colgate? The United States is not a party to that contract. While it may be all right for Congress to deal with any contract to which the Government is a party, ${ }^{6}$ it is acting in a different capacity (its general sovereign capacity) if it attempts to change a contract to which it is not a party.

In reality the Government does not wish to change the price received by the supplier. Its real purpose is to exact money from the supplier. If Colgate reduced the price to the jobber or gave the jobber a refund on account of an excessive price, the Government would not be benefited. The cost of the ship would remain unaffected.

In the case of such a manufacturer as Colgate, who is in the chain of suppliers who contribute to war contracts, what the Government does is not "repricing." If it decides that the price paid to Colgate was too high and exacts money from Colgate, pretty certainly this action cannot be defended as a repricing of a war contract. Here we have a contract between Colgate and its distributor for the sale of so many cakes of soap at so much per cake, a contract validly entered into by two parties without fraud, each of whom is still satisfied with the bargain. By no process of reasoning can power of Congress to change that contract be discovered.7

' But one should be cautious about conceding even that much. See Mr. Justice Brandeis' opinion in Lynch v. United States, 292 U.S. 57 I (1934); also the opinion of the Court in United States v. Bethlehem Steel Corp., 315 U.S. 289 (1942), and in Perry v. United States, 294 U.S. $33^{\circ}$ (1935), where the Court said flatly, at page 354 : "We conclude that the joint resolution of June 5,1933 , in so far as it attempted to override the obligation created by the bond in suit, went beyond the congressional power."

7 It cannot be done under the proprietary powers of Congress. The question of whether it might be done under sovereign powers (war powers, police power, etc.) is too broad for thorough discussion here. Under the case of Norman v. Baltimore \& Ohio R.R., 294 U.S. 240 (I935), it would seem that changes in existing contracts might be made if the change is made pursuant to action within the Constitutional powers of Congress. For instance, there the Court said, at $3 \circ 9$, "There is no Constitutional ground for denying the Congress the power expressly to prohibit and invalidate contracts previously made, and valid when made, when they interfere in the carrying out of the policy it is free to adopt." However, a condition precedent to the application of this statement to this situation is the determination that a "policy it is free to adopt" exists, which involves considerations of the limits of congressional power. The only power Congress is free to use to accomplish this end would seem to be the power to tax. 
No matter how much dust may be thrown up, it is quite certain that in the situation above outlined, what the Government is doing is to appropriate part of Colgate's profit. It does not examine into the price of the soap in the market. In practice, the problem is treated as one of accounting. The "renegotiators" very often say, "Your prices may be all right but you have just made too much money. Look at your increased volume-your return on your investment-your profit, as compared to base period years." One board will say, "We never allow more than ten per cent profit on gross before taxes nor more than three per cent profit after taxes." The Government simply determines how much of Colgate's profit to exact from it.

How then shall we describe this exaction? There is only one answer. It is a taxation of profits.

By this time someone will ask impatiently, "What is the difference whether you call it renegotiation or repricing or taxation?" The words make no difference. But the real substance of the performance does make a difference. Assume, for the moment, that it is all right for the Government as a buyer to deal with its own vendors and change the contract price. It certainly does not have the same power to deal with a contract to which it is not a party. Any money it demands in that case cannot be in its capacity as buyer but in its governmental capacity dealing with citizens generally. In this instance it is employing its general power to tax.

But there are difficulties about this particular tax. In the case of ordinary taxation the law itself imposes the tax. The taxpayer is liable whether or not any official does anything. It is the citizen's duty to come forward and pay his tax. Heavy penalties are imposed for failure. But the exaction which we are now considering is not imposed by laze. The Secretary is given the power to select the individuals and to determine the amount of the exaction. If he makes no demand the citizen goes free. Not only is the person to be taxed selected by the Secretary, but the amount of the exaction is left wholly to his discretion. Therefore, of three individuals in precisely the same situation profitwise, one the Secretary may tax heavily, the next one lightly, and the third he may exempt entirely. In practice, this actually occurs. Official apprehension on this score has recently prompted "over all industry" renegotiation. But this is no cure. Discrimination is inherent in the system.

Even the most enthusiastic anti-profiteers will concede that at least this is an undesirable method of imposing taxation. They will defend it by saying that, bad as it is, it is necessary because in no other way can profits made from war be reclaimed. If that were true, one might forget one's 
objections. But it is not true. The subject could be covered much better by a regular tax law administered by the regular tax officials. If it be said that such a law would have to be a general one and would cover nonwar profits as well as war profits, the answer is that this is certainly true and that that is what ought to be true.

Here we touch on one of the most widespread erroneous conceptions. There is no reason for labeling as war profits some profits and reclaiming a portion of them while exempting other profits. In a totalitarian war, all profits are war profits. There is no difference between the profit made by Colgate on soap sold to someone in the chain of performance of a war contract and profit on soap sold to Washington hotels. The war has determined the demand and the price in the one case just as much as in the other.

A distiller sells alcohol to the War Department and sells whiskey to soldiers. One profit is just as much a war profit as the other. Why exempt the profits of railroads, restaurants, movie companies, farmers? They are all profiting by the war. Why would it not be better to reach all war profits instead of some war profits?

If it be said that a regular tax law would not permit the flexibility and discretion of the renegotiation law, the answer is that this is the very reason why the exaction should be by way of taxation. The unlimited power which price adjustment boards can today exercise over business, the terror they can inspire, is one of the most reprehensible features of the present system.

Does someone protest that business could not stand a tax rate which would equal the regular tax plus the amount taken by way of renegotiation? But business is already standing it. Either the total exaction (regular tax, plus renegotiation refund) is too severe an exaction, or the same total exaction could be imposed by regular taxation. If it be concluded that the businesses now being renegotiated can stand that total exaction, then all other business enjoying similar profits could stand an equal exaction. The only difference would be that the exaction would be fixed by law, and would apply to all, not merely to some, excessive profits.

It seems not to be appreciated that the tax imposed by price adjustment boards is a roo per cent tax. The entire excessive profit is confiscated. If a price adjustment board determines that one million of a company's profit is excessive, it takes the full million-not a percentage of the excessive amount. Obviously by this means every bit of incentive is destroyed. Congress has never before enacted an excess profits tax that did not leave the manufacturer something. Heretofore some incentive 
has always been left-some reward for conducting business efficiently and avoiding waste. But in this month of April, I944, every manufacturer dealing with the Government knows that any profit he makes above the line fixed by price adjustment boards will be confiscated. What is the effect on the manufacturer? Will he watch the corners? Or will he say, "Here is a million dollars which the Government is going to take from me, but which I may be able to experiment with at no cost to myself. I can spend it for advertising, or for welfare of employees, or for experimentation, or I can just let my business go slack. I will not suffer, the Government will do the suffering."

If the roo per cent tax were levied on all war profits, we might hope for an earnest effort to keep down excess costs. But when owners of some war profits are singled out for Ioo per cent confiscation at the arbitrary whim of War Department employees, it is only human nature to resent the discrimination. Will it be surprising if the excessive profit melts away so that nothing is left for the Government to confiscate?

Renegotiation as practiced contains indefensible inequalities. Contracts of less than $\$ 100,000$ were exempted by the 1942 Act. This has been raised to $\$ 500,000$ in the I943 Act. The I942 Act exempts suppliers of raw materials, no matter how great their profits. The 1943 Act continues this and grants further exemptions to suppliers of office supplies and suppliers of farm products. Railroads and power companies are exempted. In any symmetrical tax law why should the suppliers of articles to be used in the office of a factory be exempted while suppliers of articles to be used elsewhere in the factory are not exempted? Profits on a typewriter sold to a factory are exempted; profits on a wheelbarrow sold to a factory are not exempted. Why should the suppliers of raw materials be exempted, when the suppliers of fabricated articles are not exempted? If the supplier of $\$ 400,000$ worth of material makes a swollen profit, why should he be exempted, and not exempted if his supplies reach $\$ 500,000$. Why should the huge profits of railroads escape? The irrational character of the approach to the subject is shown by the fact that the Senate committee approved an exemption of machine tool builders who supply machine tools to factories. The same Senate committee voted to exclude all canned foods.

All of this shows the extreme confusion with which the subject has been approached. It stems from confusing the question of price with the question of profits. 
CONCLUSION

I. Possibly it may be all right to give the War Department, the Navy Department-procurement agencies generally-power to renegotiate prices of things they buy. However that may be, they should have no authority to deal with prices which merely may affect the prices of things they buy. To give them that power is to give them control over our entire economy. The subject is bound up with inflation, wage levels, cost of living, and taxation. While some of the more vocal representatives of the War Department would apparently like to take over the whole subject, they should not be permitted to encroach on the domain of the OPA.

2. If, notwithstanding renegotiation by the procurement agencies within their limited field, and the control of prices by the OPA, excessive profits are secured, that matter should be dealt with by taxation, by a law universal in its application, with no distinction made between profits derived from furnishing materials to the Government and profits derived from other activities. There should be no discrimination in favor of the profits of some businesses-such as movie houses, railroads, restaurants, hotels, farmers, etc. A high excess profits tax should recover a liberal amount of all excessive profits "from whatever source derived." 